Editorial

Alistair Ross

Institute for Policy Studies in Education, London Metropolitan University

\title{
Editorial: Minorities, Migrants and Citizenship Education
}

The term Citizenship Education is generally used to mean teaching and learning about the social and political relationships involved in living together in societies:

citizenship is used to refer to both rights and identities, rather than to the formal status of being a citizen of a particular state. But citizenship education also needs to address how societies that include citizens who have come from other states are incorporated and live together: how majorities deal with new arrivals and minorities.

The provision that a society makes for minorities, such as an immigrant minority, critically reflects on the strength and commitment to its conception of citizenship. Moreover, the way in which its educational system teaches about those of migrant or minority descent should demonstrate its understanding of inclusive citizenship education and of its commitment to human rights. Minority and Migrants' rights are set out in a range of United Nations and International Labour Organisations charters and conventions, and include rights to education. Many of these are not observed, or only partially observed, in many countries. Citizenship education should be clearly involved in how educational provision is made for and about migrants in our societies, a particularly vulnerable minority.

Alexander de Tocqueville wrote, in Democracy in America:

If ... a man possessing absolute power may misuse that power by wronging his adversaries, why should not a majority be liable to the same reproach?

Men do not change their characters by uniting with one another; nor does their patience in the presence of obstacles increase with their strength.

(1835/2003: Chapter 15, Book 1)

Christian Joppke makes a similar point in his recent book, Citizenship and Immigration (2010). His central - and compelling - thesis is that the concept of citizenship is brought into focus and defined through its relationship with migration: the introduction of the non-citizen into a state establishes the character of the nature of the status, rights and identity that citizenship confers in that state. Citizenship can mean the conferment of a status, the entitlement to rights, or the confirmation of an identity. Joppke argues that there has been little mutual awareness and dialogue between the literatures on these three aspects, but that some synthesis is critically necessary - necessitated by, and provided by, the issue of migration. His central claim is that citizenship is no longer nationally distinctive, but has become increasingly inclusive and universalistic - 'citizenship's internally inclusive core has softened its externally exclusive edges' ( $\mathrm{p} 31$ ) - particularly so in Europe. The liberalisation of access to citizenship that has come through the more widespread acceptance of $j u s$ soli and of dual nationality, and the introduction of lower thresholds for naturalisation has been countered by two recent trends - restrictions on Muslim immigrants because of their perceived deficits in integration, and the 're-ethnicization' of citizenship to give rights to those who have migrated from the diasporic countries of Europe. Immigration also is increasingly tied to the rights of citizenship. 
This issue of Citizenship Teaching and Learning focuses on how citizenship education addresses - or does not address - the presence of minorities and migrants in our midst. The first four articles address issues of education and migration: not just citizenship education for migrants, but how education, and citizenship education in particular, should respond to include all young people, migrant and native, in a common programme of understanding and living together.

Miquel Àngel Essomba begins with an overview of European Union policies towards education in the context of diversity: how do various European states, and the European Commission, develop a unity of purpose in ensuring that children and young people from migrant backgrounds are prepared for successful school achievement. He describes in particular the Sirius networking programme that he directs, that centres on how policies are implemented, rather than how they are constructed - a perspective that is continued in the following three articles.

In the south-eastern United States of America, Ana Solano-Campos examines how an International Baccalaureate school addresses the ways in which the high proportion of refugee children on its roll 'say and do' citizenship. She explains how national testing regimes can create particular tensions and obstructions to creating common civic spaces in the school, and how this particular school rises above these constraints. In this case, the testing for the No Child Left Behind funding programme, however wellintentioned, holds up the individual and group learning needs of the young people in the school. This is not an uncommon issue, and one that programmes of international educational competition such as PISA tend to exacerbate.

Sweden has a better-than-average reputation for the way its educational policies address the needs of young people of migrant origin (MIPEX III, 2011). Jan Grannäs Examines how young people of 16 to 19 years of age construct themselves as citizens, looking particularly at migrants, but in a framework (like Hortas, below) that enables comparisons to be drawn with native Swedish compatriots. He suggests that teachers and young migrants themselves both perceive the migrant group as less politically mature that the native group, and less willing to see themselves as political actors, despite the policy imperatives and programmes of practice that emphasise the development of citizenship and support for migrant groups un the educational system.

Citizenship education that addresses issues of minorities - indeed, any educational practices that address minorities - should not be seen as education 'for' the minority group, something that is inflicted on them. This point is made in the article by Maria João Barroso Hortas. Her detailed analysis of learning and friendship in two areas in metropolitan Lisbon shows the significance of including all young people, migrant and host, in educational programmes, and of involving families and local communities. Her findings show that citizenship and social inclusion is particularly fostered when it draws in all young people and their families.

In the final article in this issue, Tatjana Zimenkova addresses the way in which citizenship educational needs of minorities are caught between educational policies (at both European and national level) that celebrate 'diversity' and other policies that focus on issues of inequality and attainment. Within citizenship education diversity education and approaches to inequality are decoupled, with potentially devastating 
consequences for minorities that are subject to exclusionary practices in society. While the previous papers have focussed on migrant minorities, this paper examines the consequences for young people from the Lesbian, Gay, Bisexual and Transgender communities. Narratives that focus on the celebration of diversity alone effectively disempower minorities and leads to self-exclusion of learners who are not listed in the minorities identified to be 'celebrated'.

I would like to conclude by thanking the special editorial board that has overseen the construction of this issue. Carole Hahn (Emory University, USA), Nanny Hartsmar (University of Malmö, Sweden), Yvonne Hébert (University of Calgary, Canada), Thomas Huddleston (Migration Policy Group, Brussels, Belgium) and Ian Davies (University of York, UK) have contributed from the construction of the original call for papers to the sign-off of the articles finally selected.

de Tocquville, A. (1835/2003) Democracy in America, trns G Bevan, London: Penguin Books

Joppke, C (2010) Citizenship and Immigration, Cambridge: Polity Press 2010

MIPEX III (2011) Migrant Integration Policy Index III, Brussels: Migration Policy Group/British Council 